\title{
Construindo gênero em quatro décadas e meia de Miss Universo
}

\author{
Miss Universo: um olhar \\ antropológico. \\ BATISTA, Ana Maria Fonseca de Oliveira.
}

Florianópolis: Insular, 2013. 232 p.

O livro Miss universo: um olhar antropológico é fruto de uma dissertação elaborada a partir de pesquisa e análise de quatro décadas e meia do concurso, entre os anos 1960 e 1990 . A obra contribui para os estudos de gênero ao discutir um espaço onde se dá a construção coletiva desta categoria pela naturalização da beleza mostrando não só como a ideia de beleza é construída a partir de critérios definidos culturalmente, mas também que a beleza de uma mulher e a sua feminilidade podem precisar de muito esforço para serem construídas. O trabalho defendido em 1997 apresenta-se deveras atual, tanto pela ainda presente repercussão social do evento nele discutido, quanto por somar aos estudos relativos a gênero, corpo e beleza em tempos nos quais o "culto à beleza" ultrapassa classes sociais e faixas etárias, e é fortemente influenciado pela mídia.

A autora se fundamenta em conceitos desenvolvidos por Clifford Geertz' (1973) e apresenta neste trabalho uma "descrição densa" do concurso de Miss Universo como "cultura", "teia de significados" que constrói e reitera os valores associados ao gênero, principalmente no as- pecto "beleza". Por ser essa "teia de significados" formada por vários sujeitos e suas vozes, ela propõe o entendimento do Miss Universo como uma "cultura polifônica" com diversos registros e diálogos.

O livro está divido em cinco capítulos. No primeiro deles, denominado "A pesquisa: referencial teórico e metodologia", relata-se a "Antropologia que se pretende praticar", como uma situação textual, explicitando a natureza dialógica do ser e da vida social. A autora parte do entendimento de que o evento "Miss Universo" é uma situação textual e, para realizar um estudo completo no sentido Maussiano, ${ }^{2}$ deve-se realizar um estudo do concreto, contextualizando e explicitando o que está sendo estudado e em que condições. Ainda nesse capítulo, a autora aponta sua metodologia de pesquisa e declara que compreende a etnografia não como uma questão de método, mas como um esforço intelectual. Assim, realiza sua descrição densa ouvindo diferentes sons: das entrevistas, dos áudios, das filmagens, e vendo diferentes imagens: das fotos, das matérias de jornal, das capas de revista.

No capítulo seguinte, a autora aponta o que entende por gênero e beleza. Faz uma rápida reconstrução das ideias de gêneros enquanto papéis sociais aprendidos e esclarece que esses papéis não são universais, de modo que padrões de beleza e feminilidade são variáveis conforme os contextos. A autora trata da categoria gênero segundo a perspectiva da Psicologia apontada por Valter Stoller ${ }^{3}$ (1968), esclarecendo as três instâncias nas quais esta 
categoria se articula, sendo elas a atribuição de gênero, a identidade de gênero e o papel de gênero. Enfatiza também, a partir de Marta Lamas, ${ }^{4}$ que os estereótipos discutidos em seu trabalho surgem do papel de gênero, que são as "normas e prescrições que a sociedade e a cultura ditam sobre o comportamento feminino e masculino" (p.48). Encerrando o capítulo, conta "uma pequena história da beleza" relatando como o ideal de corpo feminino sofreu transformações ao longo da História, pontuando como essa questão aparece para o movimento e a teoria feminista.

Ao longo do terceiro capítulo, "O Miss Universo: uma etnografia", encontramos a história do concurso, sua organização, seus atores sociais e as transformações por que passou - desde formato, patrocinadores, transmissão e divulgação, premiação, vestimentas, atividades até as características definidoras (formal e informalmente) das candidatas que participariam do concurso. Aqu se destaca o discurso nativo, que apresenta o evento com "um caráter de glamour e mundanismo", envolvendo "glória, dinheiro", a exposição física das mulheres e a "independência" das misses, ao mesmo tempo que as regras do concurso e as entrevistas, conduzidas de forma a constranger as concorrentes diante do poder do entrevistador, passam mensagens conservadoras, reforçando a "mística feminina". Sendo esta última definida por características como "fragilidade, dependência, emotividade e passividade sexual".

O quarto capítulo discute definições de beleza já conhecidas e relaciona-as ao "eterno feminino", que nada mais é que a idealização da mulher e um culto à beleza. Compreende-se então os concursos de beleza como uma manifestação legítima desse culto e também como um espaço de constante repetição da ideia da beleza como natural, ainda que seja definida por critérios. É nesse momento que se destacam as demais características exigidas para ser "Miss Universo", afinal, "não basta ser bela". Características comportamentais relacionadas à "mística feminina" devem ser demonstradas e são reiteradas pelas regras do concurso. Concluindo - capítulo, a autora aponta como as transformações no ideal de corpo, de corpo feminino e no ideal de feminino incidiram no concurso.

O último capítulo, "Concepções de beleza no Miss Universo como um espaço de construção de gênero", desenvolve o argumento central do trabalho: a análise desse concurso como um espaço importante de construção de gênero na segunda metade do século XX. A beleza no Miss Universo tem um perfil físico e comportamental. Este último é puritano, conservador e centrado no capital. Eis que esse perfil é disfarçado pela presença de tipos de mulheres variados, dos cinco continentes, e dos valores ditos modernos. Dada a cobertura midiática do concurso, entende-se que ele é estruturador de identidades, não apenas reproduz concepções já inculcadas na sociedade como também reitera e produz novas concepções que embatem diálogos e transformações com os atores envolvidos nesses processos.

Ao discutir "quais foram os ideais de beleza e feminilidade enfatizados pelo Miss Universo nas décadas de 1950 a 1990 no Brasil", a autora demonstra que não só os papéis de gênero, mas também um de seus aspectos, a beleza, foram naturalizados. Ao discutir a "mística feminina", o culto à beleza e o "eterno feminino", deixa claro que o Miss Universo não é apenas um evento de "beleza", mas também sobre comportamento e, portanto, o que define como beleza vai além da aparência, atingindo a esfera do comportamento.

É importante destacar, ainda, como, ao longo dos anos, o concurso Miss Universo e outros concursos de beleza acabam por demonstrar que as construções do corpo e da beleza podem ser bastante árduas, logo, dignas da meritocracia. Além disso, que essa construção irá realizar-se de acordo com os papéis de gênero, os quais se espera que sejam seguidos. Constroem-se, portanto, não apenas ideais de corpo e beleza, mas um sistema em que mulheres e homens são definidos por normas e prescrições culturais de comportamento. Estudiosos/as, interessados/as, em discutir espaços e comportamentos que produzem, incorporam, reiteram e recriam gênero, encontram reflexões importantes nesse trabalho.

\section{Notas}

' Clifford GEERTZ, 1989

${ }^{2}$ MAUSS, Marcel, 1988.

${ }^{3}$ STOLLER, Valter, 1986.

${ }^{4}$ LAMAS, Marta, 1986.

\section{Referências}

BATISTA, Ana Maria Fonseca de Oliveira. Miss Universo: um olhar antropológico. Florianópolis: Insular, 2013.

GEERTZ, Clifford. A Interpretação das Culturas. Rio de Janeiro: Editora Guanabara Koogan, 1989[1973]. $323 \mathrm{p}$. 
LAMAS, Marta, "La antropologia feminista y la categoria 'gênero'". Nueva antropologia. v. 32 , n. 30 , p. 172-198, 1986.

MAUSS, Marcel, 1988. Ensaio sobre a Dádiva. Trad. De Antonio Filipe Marques, Lisboa: Edições 70, [1950], 209 p.
STOLLER, Valter, 1986. Antropologia da Literatura - A obra literária como mediação do simbólico. Dissertação de Mestrado, Rio de Janeiro, Museu Nacional, $156 \mathrm{p}$.

Silvia Beatriz Mendonça Secretaria de Estado de Educação

1014 Estudos Feministas, Florianópolis, 22(3): 987-1014, setembro-dezembro/2014 